\title{
Use of millet grain in weaning pigs diet: effects on performance and health status
}

\section{Lefter Nicoleta Aurelia', Hăbeanu Mihaela*1, Gheorghe Anca1, Idriceanu Lavinia ${ }^{1}$}

*Corresponding author: mihaela.habeanu@ibna.ro

${ }^{1}$ Laboratory of Animal Nutrition, National Institute of Research and Development for Biology and Animal Nutrition, INCDBNA-IBNA Balotesti, Romania

\section{ABSTRACT}

The effect of feeding a diet containing 25\% millet grain on performance and plasma metabolic profile was evaluated in weaned piglets during 21 days trial. A total of 40 pigs with an $8.14 \pm 1.08 \mathrm{~kg}$ average body weight (BW) was weaned at $28 \pm 3$ days of age and divided into the control group (C) and the experimental group (M). The $C$ group $(n=20)$ received a conventional diet based on the corn-triticale-soybean meal while in the $M$ group $(n=20)$ received 25\% millet grain $c v$. Marius replaced triticale (2 replicates per group). At the end of the post-weaning period, the performances (BW; average daily feed intake, ADFI; average daily gain, ADG; feed: gain ratio, F: G ratio) and plasma metabolic profile (lipid, protein, enzyme, mineral) were evaluated. A slow, but not significant increase was observed for the BW $(+6 \%)$, ADG $(+12 \%), \mathrm{ADFI}(+5 \%)$ and $\mathrm{F}: \mathrm{G}$ ratio $(+7 \%)$ of pigs fed $\mathrm{M}$ diet. No effect $(\mathrm{P}>0.05)$ of dietary treatment on plasma metabolic profile was observed. However, the concentrations of triglyceride $(-15 \%, \mathrm{P}=0.089)$, total cholesterol $(-14 \%$, $\mathrm{P}=0.060)$ and aspartate aminotransferase enzyme activity $(-16 \%, \mathrm{P}=0.095)$ tended to decreased while inorganic phosphorus $(+11 \%$; $\mathrm{P}<0.04)$ had increased in the $\mathrm{M} v$ s. C diet.

The present study indicated that the replacement of $25 \%$ millet grain to triticale in weaned piglet's diet, maintains the performances and blood plasma parameters within the physiological ranges, beneficial to the health status.

Keywords: performance, plasma, weaned piglets, health status, millet

\section{INTRODUCTION}

Cereals are important nutrients in human and, also in animal nutrition. Nowadays, climate change, environmental deterioration and limiting yields overhang cereal production and world food security (FAO, 2011). 
As the human demand for food and meat products increased, alternative sources to cereals have becomes a major challenge (FAO, 2017). Millets, the small-seeded species of cereal are important grain crops in arid and semi-arid parts of the world (Amadou et al., 2013). In Europe, millet varieties are underutilized or cultivated in small amounts and usually used as feed for pets and less for piglets (Devi et al., 2014; Habiyaremye et al., 2017). However, with increasing concerns about adverse changes in environmental quality with negative effects on the production of cereals (corn, triticale., e.g.), millet having short crop cycle and several agrotechnical and nutritional benefits have good prospects to be present on the cereal world market, including in Romania as potential feed source (Changmei and Dorothy, 2014; Singh \& Chauhan, 2019). Furthermore, millet has resistance to insect damage and disease (Adekunle, 2012; Yenagi et al., 2013; Dipnarayan et al., 2016).

Millet feeds due to the presence of polyphenols (phenolic acids and glycated flavonoids) with antioxidants properties (Changmei and Dorothy, 2014; Singh and Chauhan, 2019) could have significant health benefits for piglets exposed stressors (Li et al., 2019; Lefter et al., 2020). The gluten deficiency of millet grain is directly related to the protein digestibility. Thus, as millet do not contain gluten, is easy to digest and hence, is recommended for the nourishment of humans and young animals (Habiyaremye et al., 2017).

Indoor pig production systems present social, environmental, and nutritional challenges particularly in the weaning period with essential repercussions on animals' metabolism (Sugiharto et al., 2014; Hăbeanu et al., 2017; Reis de Souza et al., 2019). Moreover, weaning stress as a systemic response can decrease feed ingestion, nutrient absorption, alters the performances and increased piglets susceptibility to diseases (Hăbeanu et al., 2015; Luo et al., 2016).

Blood, this complex fluid, plays essential functions in living systems and often reflect the functional activity of an organ or tissue and thus, could be an easy means that provide important information about the effects of the different nutritional regimen used in young animals feeding (Radostits et al., 2000; Hellwing et al., 2007; Schwartz and Conley, 2020) such as millet-based diets.

In this context, the study aimed to evaluate the effects of $25 \%$ dietary millet grain on piglets performance and plasma metabolites in weaning period.

\section{MATERIALS AND METHODS}

\section{Animals and study design}

The experimental design was approved by the National ResearchDevelopment Institute for Biology and Animal Nutrition (INCDBNA Balotesti) ethics committee (No. 1493/2018). The diet trial was conducted at the 
experimental farm of the institute. The piglets used in the study were treated following the EU Directive 2010/63/EU (OJEU, 2010).

The experiment was conducted during 21 days after weaning on 40 hybrid Topigs piglets. The piglets (20 male and 20 female) weaned at $28 \pm 3$ days of age with average initial body weight (BW) of $8.14 \mathrm{~kg} \pm 1.08$ were divided into two groups ( $\mathrm{n}=20$ per group, 2 replicates/group) based on their BW: i). the control group (C), fed with a corn-triticale-soybean meal-based diet; ii). the experimental group (M), fed a compound feed similar to that of group C, where $25 \%$ of millet grain replaces triticale. The experimental diets were isocaloric and isoenergetic with similar content in essential amino acids (lysine, methionine + cysteine), $\mathrm{Ca}$ and $\mathrm{P}$. The respective composition of the experimental diets is shown in Table 1 . Feed was offered two times a day (9:00 and 14:00 h), and feed intake was recorded daily.

Table 1. Experimental diets

\begin{tabular}{lcc}
\hline Ingredients g/kg (as-fed basis) & C & Diets \\
& M \\
\hline Corn & 441.1 & 444.0 \\
Triticale & 250.0 & - \\
Millet & - & 250.0 \\
Soybean meal (44\%, crude protein) & 180.0 & 180.0 \\
Corn gluten & 30.0 & 30.0 \\
Milk powder & 50.0 & 50.0 \\
Soybean oil & 15.0 & 10.0 \\
DL-methionine & 0.4 & 1.0 \\
L-Lysine & 3.4 & 3.9 \\
Calcium carbonate & 17.0 & 16.2 \\
Monocalcium phosphate & 1.0 & 2.8 \\
Phytase & 0.1 & 0.1 \\
Salt & 1.0 & 1.0 \\
Choline premix & 1.0 & 1.0 \\
Vitamin-mineral premix P1+2 & 10.0 & 10.0 \\
\hline Chemical composition & & \\
\hline Metabolizable energy (MJ /kg) ${ }^{1}$ & 13.6 & 13.6 \\
Crude protein & 187.5 & 182.9 \\
Lysine & 12.0 & 12.0 \\
Methionine + cystine & 7.2 & 7.2 \\
Calcium & 9.0 & 9.0 \\
Phosphorus & 7.8 & 6.5 \\
Cellulose & 37.3 & 38.2 \\
Ether extract & 36.9 & 34.5 \\
\hline
\end{tabular}

Note: $\mathrm{C}$ - control diet; $\mathrm{M}$ - millet diet. ${ }^{1}$ Metabolizable energy was calculated based on feed composition and theoretical coefficients. 
The piglets were weighed at first day after weaning, and at 21 day after weaning crises period, in order to determine the performances (BW; average daily feed intake, ADFI; average daily gain, ADG; feed: gain ratio, F: G ratio).

\section{Blood metabolites assays}

At the end of the 21 days of the diet protocol, blood samples from 10 pigs/group were taken from the jugular vein. Vacutainer tubes coated with lithium heparin $(6 \mathrm{ml})$ were used for the test of clinical plasma. Subsequent, blood samples were centrifuged at $3000 \times \mathrm{g}$ for $15 \mathrm{~min}$, and supernatant (plasma) was harvested and stored at $-80^{\circ} \mathrm{C}$ for blood biochemistry analysis.

Plasma metabolites, triglycerides (TG), total cholesterol (T-Chol), highdensity lipoprotein cholesterol (HDL-C), low-density lipoprotein cholesterol, (LDL-C), total protein (T-Pro), albumin (Alb) uric acid (UA), creatinine (Cre), total bilirubin (T-Bil), urea nitrogen (BUN), aspartate aminotransferase (AST), alanine aminotransferase (ALT), lactate dehydrogenase (LDH) and creatine kinase (CK), calcium (Ca), magnesium (Mg), inorganic phosphorus (IP) were determined using a chemistry analyser Spotchem EZ SP-4430 (Arkray, Japan). The LDL-C was calculated by the Pond et al. (1997) equation.

\section{Statistical calculations}

Data are expressed as means and standard error of the mean (SEM). Data were analysed using the SPSS V.20 (2011) software, General Linear Model procedure. A P-value $<0.05$ was considered statistically significant and as a trend at $0.1<\mathrm{P}>0.05$. Pearson's correlation was used to assess the relationship between plasma metabolites.

\section{RESULTS AND DISCUSSION}

\section{Performance}

According to our previous study (Lefter et al., 2020) and similar research (Saleh et al., 2013; Kaur et al., 2014), millet provide important nutrients to piglet diets: energy (ME of approximately $3052 \mathrm{kcal} / \mathrm{kg}$ ), relatively high protein $(10 \%)$, limiting amino acids $(0.20 \%$ lysine; $0.34 \%$ methionine + cysteine; $0.47 \%$ threonine), minerals $(0.28 \%$ total phosphorus; $0.03 \%$ calcium), vitamins and dietary fibre.

The results of the present study indicate that the substitution of triticale with millet grain in piglets diet not significantly affected $(\mathrm{P}>0.05)$ the average BW, ADG, ADFI and F: G ratio (Table 2) at the end of 21 days of investigation.

Little information about the capacity of different types of millet grain to support performance in young pigs is currently available (Adeola and Orban 1995; Lawrence et al., 1995; Bastos et al., 2006; Li et al., 2019; Lefter et al., 2020). Summarizing the above-mentioned studies concerning growth 
performance of piglets at 9 weeks of age fed up to $60 \%$ millet diets to that of pigs fed corn-based diets, similar or minimal differences (Li et al., 2019) were observed for ADG, ADFI, and F: G ratio, respectively.

Table 2. Performance of weaned piglets fed a millet grain diet

\begin{tabular}{lcccc}
\hline Item & C & M & SEM & P-value \\
\hline No. of pigs, head/group & 20 & 20 & - & - \\
Body weight at weaning, kg & 8.14 & 8.15 & 0.196 & 0.840 \\
Body weight after 21-days, kg & 13.06 & 13.86 & 0.357 & 0.315 \\
ADG, g/day & 0.250 & 0.285 & 0.011 & 0.850 \\
ADFI, kg/day & 0.593 & 0.625 & 0.021 & 0.463 \\
F: G ratio, g & 0.422 & 0.456 & - & - \\
\hline
\end{tabular}

Note: $\mathrm{C}$, control diet; $\mathrm{M}$, millet grain diet; $\mathrm{ADG}$, average daily gain; ADFI, average daily feed intake; F: G ratio, feed: gain ratio.

Several studies have examined the effect of up to $75 \%$ different types of millet grain in maize/soybean-based diets fed to growing-finishing pigs with no differences (P>0.05) on ADFI, ADG or F: G ratio due to treatment (Moreira et al., 2007; Oliveira et al., 2007).

Millet grain has, been successfully used as a substitute for corn in the diets of poultry (Goodarzi et al., 2011; Baurhoo et al., 2011; Oso et al., 2014; Batonon-Alavo et al., 2015; Cisse et al., 2016; Yilkal et al., 2018) and ducks (Adeola et al., 1996). The results showed that diets containing millet led to similar performance as the corn-based diet for all parameters.

Corroborating evidence related to the proper-balanced amino acid profile, high essential amino acid concentrations with a high digestibility rate of these amino acids (Adeola and Orban, 1995; Yin et al., 2002; Batonon-Alavo et al., 2015) and the absence of adverse effects on productive performances, millet grain may be used as an alternative grain source for nonruminant animals, especially in young pigs feeding.

\section{Plasma metabolic profile}

The results on plasma biochemical parameters, as markers for health status are summarized in Table 3.

The dietary millet decreased the concentrations of TG $(-15 \%, \mathrm{P}=0.089)$, $\mathrm{T}$ Chol $(-14 \%, \mathrm{P}=0.060)$ and LDL-C $(-56 \%, \mathrm{P}>0.05)$ in comparison with $\mathrm{C}$ diet, whereas the concentration of HDL-C slightly increased $(6 \%, P>0.05)$, as shown in Table 3. However, the plasma lipid parameters were within the reference ranges. After our knowledge, no other studies similar with our study were found in literature. However, decreased TG and T-Chol levels have been 
reported in an alloxan-induced diabetic rat model, fed diets formulated with finger millet and Kodo millet, incorporated at 55\% in the basal diet (Hegde et al., 2005). Plasma TG and T-Chol were reduced in diabetic mice model fed $1 \%$ extract from hog millet (Mi-Young Park et al., 2011) or 20\% finger millet seed coat matter (Shobana et al., 2010). A beneficial effect of dietary protein concentrate of foxtail or proso millet on lipid metabolism was also reported in some studies (Nishizawa and Fudamoto, 1990; Nishizawa et al., 1995; Shimanuki et al., 2006) conducted on mice or rats during 21 days experimental period. Due to differences in the analytical methods, experimental conditions or other factors (Pond et al., 1997), further investigations on weaning piglets are needed to sustain this positive corelation between lipid metabolism and intake of millet grain under normal dietary conditions.

Table 3. Plasma metabolic profile of weaned pigs fed a millet grain diet

\begin{tabular}{|c|c|c|c|c|c|c|}
\hline Item & Parameter & Limits & $\mathrm{C}$ & $\mathbf{M}$ & SEM & P-value* \\
\hline \multirow{4}{*}{ Lipid } & TG, mg. dL-1 & $33-50^{1}$ & $50.38^{\mathrm{T}}$ & $43.00^{\mathrm{T}}$ & 2.17 & $0.089^{*}$ \\
\hline & T-Chol, mg. dL-1 & $67-367^{2}$ & $80.13^{\mathrm{T}}$ & $68.86^{\mathrm{T}}$ & 3.03 & $0.060^{*}$ \\
\hline & HDL-C, mg. dL-1 & - & 37.63 & 39.86 & 2.15 & 0.532 \\
\hline & LDL-C, mg. dL-1 & - & 34.44 & 22.12 & 3.20 & 0.156 \\
\hline \multirow{6}{*}{ Protein } & T-Pro, g. dL $\mathrm{dL}^{-1}$ & $5.8-8.3^{1}$ & 5.50 & 5.26 & 0.07 & 0.109 \\
\hline & Alb, g. dL-1 & $2.3-4.0^{1}$ & 3.14 & 2.96 & 0.07 & 0.247 \\
\hline & $\mathrm{UA}, \mathrm{mg} \cdot \mathrm{dL}^{-1}$ & - & 0.65 & 0.63 & 0.03 & 0.438 \\
\hline & Cre, mg. dL $\mathrm{dL}^{-1}$ & $0.8-2.3^{1}$ & 1.31 & 1.36 & 0.03 & 0.346 \\
\hline & T-Bil. mg. dL & $0-0.5^{1}$ & 0.26 & 0.29 & 0.04 & 0.405 \\
\hline & BUN, mg. dL ${ }^{-1}$ & $8.2-25^{1}$ & 9.25 & 8.13 & 0.49 & 0.262 \\
\hline \multirow{4}{*}{ Enzyme } & AST, U/L & $18-84^{2}$ & $29.75^{\mathrm{T}}$ & $25.00^{\mathrm{T}}$ & 1.42 & $0.095^{*}$ \\
\hline & ALT, U/L & $31-75^{1}$ & 58.78 & 58.69 & 1.95 & 0.982 \\
\hline & LDH, UI/L & $380-630^{3}$ & 466.00 & 497.50 & 41.86 & 0.678 \\
\hline & CK, UI/L & $146-870^{2}$ & 803.75 & 852.50 & 18.23 & 0.190 \\
\hline \multirow{3}{*}{ Mineral } & $\mathrm{Ca}, \mathrm{mg} \cdot \mathrm{dL}^{-1}$ & $6.8-14.8^{2}$ & 15.04 & 14.86 & 0.55 & 0.648 \\
\hline & $\mathrm{Mg}, \mathrm{mg} \cdot \mathrm{dL}^{-1}$ & $2-3.5^{1}$ & 2.43 & 2.60 & 0.11 & 0.426 \\
\hline & IP, mg. dL-1 & $5.5-9.3^{1}$ & $7.39^{\mathrm{T}}$ & $8.28^{\mathrm{T}}$ & 0.25 & $0.078^{*}$ \\
\hline
\end{tabular}

Note: C, control diet; M, millet grain diet. Triglycerides, TG; Total cholesterol, T-Chol; Highdensity lipoprotein cholesterol, HDL-C; Low-density lipoprotein cholesterol, LDL-C; Total protein, T-Pro; Albumin, Alb; Uric acid, UA; Creatinine, Cre; Total bilirubin, T-Bil; Urea nitrogen, BUN; Aspartate aminotransferase, AST; Alanine aminotransferase, ALT; Lactate dehydrogenase, LDH; Creatine kinase, CK; Calcium, Ca; Magnesium, Mg; Inorganic phosphorus, IP. ${ }^{1}$ Merck Veterinary Manual, 2010. ${ }^{2}$ Perri et al., 2017. ${ }^{3}$ Radostits et al., 2000. *Means within rows do not differ significantly $(\mathrm{P}>0.05)$; $\mathrm{T}=$ Tendence to be influenced by treatment.

Compared with the $\mathrm{C}$ diet, the plasma protein concentrations T-Pro, Alb, UA, Cre, T-Bil and BUN, in $\mathrm{M}$ diet remained at a similar level $(\mathrm{P}>0.05)$ and within the normal range for this category of animals (Table 3). Contrary to our 
study, increased of some blood protein fractions was reported by $\mathrm{Li}$ et al. (2019) on malnourished pigs fed on proso millet diet during 3 weeks. However, blood biochemistry analysis of T-Pro, Alb, and BUN is widely interpreted as an index of protein catabolism (Shobana et al., 2010) and reflected the efficiency of dietary amino acids supply (Abeni et al., 2018). In our study, similar concentrations of organic plasma components complemented by slightly increased $(\mathrm{P}>0.05)$ of performance, suggest that the millet diet supply adequate amino acids amount to support the piglets metabolism. Moreover, the blood UA, Cre and BUN seem to be associated with normal renal function, whereas T-Bil has been implicated in the pathophysiology of liver disease (Radostits et al., 2000; Hellwing et al., 2007). In our study, the absence of any significant differences in blood protein fractions due to millet diet also indicated a normal health state of piglets.

According to some studies (Radostits et al., 2000; Nishizawa et al., 2002; Hyder et al., 2013), the leakage of AST, ALT, LDH and CK enzymes into the blood circulation in higher quantities suggest the presence of oxidative damage induced by several factors including weaning stress (Luo et al., 2016). Elevated plasma AST and ALT have been directly related to damaged liver function (Hyder et al., 2013). CK is a sensitive indicator of injury to skeletal and heart muscles (Jurisic et al., 2015). Also, variations in the LDH activities may have profound effects on the liver, kidney, myocardium, skeletal muscle and red blood cells disturbance (Jurisic et al., 2015).

In the present study, the dietary millet tended to decrease the activity of AST enzyme ( $16 \%, \mathrm{P}=0.095)$ while the ALT, LDH and CK enzymes remained at a similar level to $C$ diet (Table 3). As was previously reported by Luo et al., (2016) the elevated level of AST enzyme in the plasma tissue of the piglets fed C diet, could be attributed to oxidative stress as a common mechanism that damaged hepatocellular function. However, we can consider that constant concentration of ALT, LDH and CK enzymes in the plasma tissue suggest that nor dietary treatment neither oxidative stress experimented by piglets contributed to the elevation of those important health markers. However, further studies are required to explore the changes within the plasma enzymes concentrations and hepatic structure of weaning piglets.

The plasma $\mathrm{Ca}$, and $\mathrm{Mg}$ concentrations were not significantly affected by the millet diet. Regarding the plasma IP, we noticed that pigs fed millet diet registered higher values $(11 \% ; \mathrm{P}=0.078)$ compared to control diet. The concentrations of all these elements were normal when compared with the physiological range of those minerals for pigs. Similarly, Lei et al. (1993) and Murry et al. (1997) observed an increase in serum IP concentration when pearl millet and different phytase levels were added to the pigs diets. Goodarzi et al. (2011) reported that foxtail millet could replace 33,66 or $100 \%$ of corn in the diet of broiler chickens without a negative effect on blood minerals. 
As shown in Table 4, a negative correlation $(\mathrm{P}<0.05)$ between plasma lipids and protein fraction was observed.

The enzyme activity of AST and CK was positively correlated $(\mathrm{P}<0.05)$.

Table 4. Pearson correlation between plasma metabolites

\begin{tabular}{llll}
\hline Item & HDL-C & T-Pro & AST \\
\hline TG & $-0.54^{*}$ & & \\
HDL-C & & $-0.59^{*}$ & \\
CK & & & $0.50^{*}$ \\
\hline
\end{tabular}

Note: Correlation is significant at the $0.05^{*}$ level (2-tailed).

\section{CONCLUSION}

The results of this study indicated that the replacement of $25 \%$ millet grain to triticale in weaned piglet's diet, maintains the performances and blood plasma parameters within the physiological ranges, beneficial to the health status.

\section{ACKNOWLEDGEMENTS}

This study was supported by the Ministry of Agriculture and Rural Development of Romania through Sectorial project ADER 9.1.4.

\section{REFERENCES}

Abeni, F., Petrera, F., Prí, A.D., Rapetti, L., Crovetto, G.M., and Galassi G. 2018. Blood parameters in fattening pigs from two genetic types fed diet with three different protein concentrations ${ }^{1}$. Transl. Anim. Sci. 2, 372382.

Adeola, O., and Orban, J.I. 1995. Chemical composition and nutrient digestibility of pearl millet (Pennisetum glaucum) fed to growing pigs. J. Cereal Sci. 22 (2), 177-184.

Adeola, O.K.D., and Lawrence, B.V. 1996. Evaluation of pearl millet for swine and ducks, in: J. Janick. (Eds.), Progress in new crops. ASHS Press, Alexandria, VA. 177-182.

Amadou, I., Gounga, M.E., and Guo-Wei L. 2013. Millets: Nutritional composition, some health benefits and processing - A. Review. Food Science and Nutrition. Emir. J. Food Agric. 25 (7), 501-508.

Bastos, A.O., Moreira, I., Furlan, A.C., Oliveira, G.C., de Fraga, A.L., Sartori, I.M. 2006. Effect of feeding increasing levels of pearl millet (Pennisetum glaucum (L.) R. Brown) grain for growing and finishing pigs. Rev. Bras. Zootec. 35 (1), 98-103.

Batonon-Alavo, D.I., Umar Faruk, M., Lescoat, P., Weber, G.M., and Bastianelli, D. 2015. Inclusion of sorghum, millet and cottonseed meal in broiler 
diets: A meta-analysis of effects on performance. Anim. 9 (7), 11201130.

Baurhoo, N., Baurhoo, B., Mustafa, A.F., and Zhao, X. 2011. Comparison of cornbased and Canadian pearl millet-based diets on performance, digestibility, villus morphology, and digestive microbial populations in broiler chickens. Poult. Sci. J. 90, 579-586.

Cisse, R.S., Hamburg, J.D., Freeman, M.E., and Davis, A.J. 2016. Using locally produced millet as a feed ingredient for poultry production in SubSaharan Africa. J. Appl. Poult. Res. 26, 9-22.

Changmei, S., and Dorothy, J. 2014. Millet-the frugal grain. Int. J. Sci. Res. 3 (4), 75-90.

Devi, P.B., Rajendran, V., Sathyaseelan, S., Nagappa, G.M., Venkatesan, B.P. 2014. Health benefits of finger millet (Eleusine coracana L.) polyphenols and dietary fiber: A Review. J. Food Sci. and Techno. 51 (6), 1021-1040.

Directive (EU) No. 63. 2010. Official Journal of the European Union, L 276, 3379.

FAO. 2011. http://www.fao.org/ag/save-and-grow/en/index.html

FAO. 2015. http://www.fao.org/3/a-i6583e.pdf

Goodarzi, B.F., Samie, A.H., Edriss, M.A., Khorvash, M., Sadeghi, G., Van Kessel, A., and Zentek, J. 2011. Replacement of corn in the diet of broiler chickens using foxtail millet produced by 2 different cultivation strategies. Poult. Sci. J. 90, 2817-2827.

Habiyaremye, C., Matanguihan, J.B., Guedes, J.D'A., Ganjyal, G.M., Whiteman, R.M., Kidwell, K.K., Murphy, K.M. 2017. Proso millet (Panicum miliaceum L.) and its potential for cultivation in the Pacific Northwest, U.S.: A Review. Front. Plant Sci. 7 (1961), 1-17.

Hăbeanu, M., Lefter, N.A., Gheorghe, A., Tabuc, C., Untea, A., Surdu, I., Ciurescu, G., Balan, C.G., Dragomir, C. 2015. Changes in certain serum and faeces parameters in weaned piglets as a response to nutritional stress. S. Afr. J. Anim. Sci. 45 (2), 164-172.

Hăbeanu, M., Lefter, N., Gheorghe, A., Tabuc, C., Dumitru, M., Ciurescu, G., Palade, M. 2017. Effects of dietary peas mixed with linseed (3:1) on the growth performance, enteritis and certain serum parameter in weaned piglets. Food and Feed Research, 44 (2), 173-180.

Hegde, P.S., Namakkal, S., Rajasekaran, T.S.,,Chandra, T. 2005. Effects of the antioxidant properties of millet species on oxidative stress and glycemic status in alloxan-induced rats. Nut. Research. 25, 1109-1120.

Hellwing, A. Louise, F. Tauson, A-H. and Skrede, A. 2007. Blood parameters in growing pigs fed increasing levels of bacterial protein meal. Brief communication. Acta Vet. Scand. 49(33), 1-4. 
Hyder, M.A., Hasan, M., and Mohieldein, A.H., 2013. Comparative levels of ALT, AST, ALP and GGT in liver associated diseases. Euro. J. Exp. Bio. 3 (2) 280-284.

Jurisic, V., Radenkovic, S., and Konjevic, G. 2015. The actual role of LDH as tumor marker, biochemical and clinical aspects. Adv. Exp. Med. Biol, 867, 115-124.

Kaur, K.D., Jha, A., Sabikhi, L., and Singh, A.K., 2014. Significance of coarse cereals in health and nutrition: A review. J. Food Sci. and Techno. 51 (8), 1429-1441.

Lawrence, B.V., Adeola, 0., and Rogler, J.C. 1995. Nutrient digestibility and growth performance of pigs fed pearl millet as a replacement for corn $^{1,2}$. J. Anim. Sci. 73 (7), 2026-2032.

Lefter, N. A., Hăbeanu, M., Gheorghe, A., Idriceanu, L. 2020. Preliminary research on growth response and health status of piglets fed millet grain as a partial replacement for triticale. Sci. Papers Ser. D, Anim. Sci. LXIII (1), 135-141.

Lei, X.G., Ku, P.K., Miller, E.R., Yokoyama, M.T., and Ullrey, D.E., 1993. Supplementing corn-soybean meal diets with microbial phytase maximizes phytate phosphorus utilization by weanling pigs. J. Anim. Sci. 71 (12), 3368-3375.

Li, X., Hui, Y., Ren, J., Song, Y., Liu, S., Che, L., Peng, X., Dai, X. 2019. Millet-based supplement restored microbiota diversity of acute undernourished pigs. bioRxiv The Preprint Server for Biology. 1-26.

Luo, Z., Zhu, W., Guo, Q., Luo, W., Zhang, J., Xu, W., Xu, J. 2016. Weaning induced hepatic oxidative stress, apoptosis, and aminotransferases through MAPK signaling pathways in piglets. Oxid. Med. Cell. Longev. ID 4768541, 1- 10.

Merck and Co. 2010. The Merck Veterinary Manual, 10th(Eds.), Merck Co., Inc., Kenilworth, NJ, USA.

Mi-Young Park, Jang, H-H., Kim, J.B., Yoon, H.N., Lee, J-Y., Lee, Y-M., Kim J-H., and Park D-S. 2011. Hog millet (Panicum miliaceum L.)-supplemented diet ameliorates hyperlipidemia and hepatic lipid accumulation in C57BL/6J-ob/ob. Mice. Nutr. Res. Pract. 5 (6), 511-519.

Moreira, I. Bastos, A.O., Scapinelo, C., Fraga, A.L., Kutschenko, M. 2007. Different types of pearl millets (Pennisetum glaucum (L.) R. Brown) on growing-finishing pigs feeding. Cienc. Rural. 37 (2), 495-501.

Murry, A.C. Lewis, R.D. and Amos, H.E. 1997. The effect of microbial phytase in a pearl millet-soybean meal diet on apparent digestibility and retention of nutrients, serum mineral concentration, and bone mineral density of nursery pigs. J. Anim. Sci. 75, 1284-1291.

Nishizawa, N., Oikawa, M., and Hareyama, S. 1990. Effect of dietary protein from proso millet on the plasma cholesterol metabolism in rats. Agric. Biol. Chem. 54, 229-230. 
Nishizawa, N., and Fudamoto, Y., 1995. The elevation of plasma concentration of high-density lipoprotein cholesterol in mice fed with protein from proso millet. Biosci. Biotech. Bioch. 59 (2), 333-335.

Nishizawa, N., Sato, D., Ito, Y., Nagasawa, T., Hatakeyama, Y., Choi, M-R., Choi, YY., and Wei, Y. M. 2002. Effects of dietary protein of proso millet on liver injury induced by D-galactosamine in rats. Biosci. Biotech. Bioch. 66 (1), 92-96.

Oliveira, V., Fialho, E.T., Lima, J.A.F. 2007. Pearl millet or sorghum diets with amino acids supplementation for finishing pig. Arch. Vet. Sci. 12 (1), 58-62.

Oso, A.O., Williams, G.A., Jegede, A.V., Sobayo, R.A., Idowu, O.M.O., Fafiolu, A.O., Sogunle, O.M., Akinola, O.S., Adeleye, O.O., Olorunsola, I.A.R., Ogunade, I.M., Osho, S.O., Obadire, F.O. Bamgbose, A.M. 2014. Effect of combination of whole millet feeding and mannan oligossaccharides supplementation on growth performance, serum biochemistry and relative organ weights of growing guinea fowl (Numidia meleagris). Liv. Sci. 159, 46-52.

Perri, A.M., O’Sullivan, T.L., Harding, J.C.S., Wood, R.D., Friendship, R.M. 2017. Hematology and biochemistry reference intervals for Ontario commercial nursing pigs close to the time of weaning. Can. Vet. J. 58 (4), 371-376.

Pond, W.G., Su, D.R., and Mersmann, H.J. Divergent concentrations of plasma metabolites in swine selected for seven generations for high or low plasma total cholesterol1,2. J. Anim. Sci. 75, 311-316.

Reis de Souza,T. C., Barreyro, A.A., Rubio, S. R., González, Y.M., García, K. E., Soto, J. G. G. Gerardo M-L. 2019. Growth performance, diarrhoea incidence, and nutrient digestibility in weaned piglets fed an antibiotic-free diet with dehydrated porcine plasma or potato protein concentrate. Ann. Anim. Sci. 19 (1), 159-172.

Radostits, O. Gay, C. Hinchcliff, K. Constable, P. 2000. A textbook of the diseases of cattle, horses, sheep, pigs and goats. Veterinary medicine, $9^{\text {th }}$ (Edn.) Saunders, London, pp. 1819-1822.

Saleh, A.S.M., Qing, Z., Jing, C. and Qun, S. 2013. Millet grains: nutritional quality, processing, and potential health benefits. Compr. Rev. Food Sci. Food Safety. 12, 280-295.

Schwartz, R., and Conley, C.L. 2020. Blood. Encyclopædia Britannica https://www.britannica.com/science/blood-biochemistry.

Shimanuki, S. Nagasawa, T., Nishizawa, N. 2006. Plasma HDL subfraction levels increase in rats fed proso-millet protein concentrate. Med. Sci. Monit. 12 (7), BR., 221-226.

Shobana, S., Harsha, M.R., Platel, K., Srinivasan, K., and Malleshi, N.G. 2010. Amelioration of hyperglycemia and its associated complications by 
finger millet (Eleusine coracana L.) seed coat matter in streptozotocin induced diabetic rats. Brit. J. Nutr. 104, 1787-1795.

Singh, S. and Chauhan, E.S. 2019. Role of underutilized millets and their nutraceuticals importance in the new era. A review. Int. J. Sci. Res. 8 (2), 2844-2857.

SPSS .2011. Statistics v. 20.0., IBM, SPSS, Inc., USA.

Sugiharto, S., Hedemann, M.S., and Lauridsen C.Plasma metabolomic profiles and immune responses of piglets after weaning and challenge with $E$. coli. J. Anim. Sci. Biotechno. 5 (17), 3-8.

Yilkal, T., Tegene, N., Negassi, A., and Yadav, K.R. 2018. Effect of dietary replacement of maize with finger millet (Eleusine coracana) grain on production performance and egg quality of White Leghorn hens. Int. J. Poult. Sci. 17(1), 40-50.

Yin, Y., Gurung, N.K., Jeaurond, E.A., Sharpe, P.H., and de Lange, C.F.M. 2002. Digestible energy and amino acid contents in Canadian varieties of sorghum, pearl millet, high-oil corn, high-oil-high-protein corn and regular corn samples for growing pigs. Can. J. Anim. Sci. 82, 385-391. 